\title{
The Department Store in Hong Kong: Local Institutional Changes and the Concession Business Model
}

\author{
Matthew M. Chew \\ Department of Sociology, Hong Kong Baptist University \\ Kowloon Tong, Kowloon, HKSAR, China \\ Tel: 852-3411-7132 E-mail: mmtchew@hkbu.edu.hk
}

\begin{abstract}
As a declining retail format, how is the department store managing to survive in Hong Kong? How has it transformed itself in response to contemporary retail environments? Are these institutional transformations different from those observed in the US and Europe? In what ways are they different and how have they shaped local department stores? This essay explores these questions through examining recent institutional changes of department stores in Hong Kong. Data for this study were collected through qualitative observation, documentary analysis, and in-depth interviews of department store managers and consultants. I find that Hong Kong's department stores have pursued a major and successful institutional transformation between 1998 and the present: they strategically abandon the conventional department store format and develop a concession-oriented one. I illustrate the special characteristics, structural benefits, and potentials problems of the concession-oriented department store format through analyses of the power relationship between concessionaire and department stores, the changing work processes in department stores, and the cost and risk implications of concessions in the contemporary retail context of Hong Kong.
\end{abstract}

Keywords: Hong Kong retailing, Department stores, Concession, Retail change, Retail management, Shopping malls

\section{Introduction}

The department store retail format emerged in the mid- $18^{\text {th }}$ century in the US and France, and steadily grew since the late- $18^{\text {th }}$ century in the UK, the US, and Continental Europe. It has been well documented that it underwent a period of decline in the past few decades in the US, Europe, and East Asia (Chong, 1996; Eurostat, 1993; May and McNair, 1977; Sternlieb and Hughes, 1987; Sun, Kay, and Chew, 2008; Willans, 1996). However, few have explored the details of how the retail format is doing outside of the US and Europe. A large number of department stores are still present around the world and there are important questions regarding them that should interest scholars of retailing. How have these department stores managed to survive? How are they transforming themselves in response to contemporary retail changes? Are these institutional transformations different from those in contemporary US and Europe? In what ways are they different and how have they shaped local department stores? This essay explores these questions through examining the case of department stores in Hong Kong. I will especially focus on how Hong Kong's department stores have pursued institutional changes and survival strategies that are quite different from those in the US and the UK.

In the context of their declining importance within the retail institutional mix, department stores are attempting to adapt themselves to contemporary retail circumstances. The somewhat similar timing of decline of the department store format around the world reflects that there are certain globally common factors undermining the format. Large overhead and inflexible cost structure are two salient examples. In addition, competition from new and improved specialty stores formats, such as efficient multiples or high-profile specialty stores, has negatively impacted on department stores everywhere. Changes in shoppers' consumption pattern towards specialized lifestyle niches constitute another factor that undermines the department store format. At the same time, given the very different social and economic circumstances across nations around the globe, there are likely to be additional locally specific factors that undermine (or benefit) the department store format in different national contexts. In response to these locally specific factors, department stores in different countries are pursuing somewhat different institutional changes to ensure survival and profitability. As a side effect of these different institutional changes, contemporary department stores around the world are developing institutional characteristics in divergent directions. The case of department stores in Hong Kong illustrates this interesting development.

\section{Locally specific factors that undermine department stores in Hong Kong}

\subsection{The development of shopping malls in Hong Kong}

The contemporary urban formation of Hong Kong indirectly and subtly give rise to certain retail geographic changes 
that are different from familiar North American and European cases. It is often said that Hong Kong urban development emphasizes a vertical direction of urban expansion (tall buildings) rather than a horizontal one (urban sprawling). Because of the relatively limited extent of urban sprawling, Hong Kong does not feature densely populated downtown districts surrounded by huge suburban or industrial areas with low population density. Because there are few suburban or industrial areas, Hong Kong does not have any greenfield or brownfield shopping malls.

There are relatively far-from-downtown urban districts in Hong Kong and these areas are almost as 'malled' as suburbs in North America and Europe during the past few decades. But the out-of-town malls in Hong Kong possess certain special characteristics that impacted on their reception of the department store format. Instead of being oriented around particular suburban areas, almost all large out-of-downtown malls in Hong Kong are based on the stations of the city's two major mass transit systems. The East Kowloon Railway and the Mass Transit Railway were both completed in the 1980s, and they link downtown areas of Hong Kong to non-downtown residential areas and relatively remote satellite towns. Since Hong Kong is one of the most densely populated cities in the world in terms of residents per land area, within the walking distance of each stations of the two railways live tens of thousands of residents. Due to the enormous traffic of people around the railway stations, large shopping malls were developed immediately next to the stations. There are a few large out-of-downtown malls (eg. those in Tuen Mun or Whampoa) in Hong Kong that are not built around railway stations. These malls are based on satellite towns or housing estates which accommodate numerous of residents. Similar to malls based on railway stations, these malls are guaranteed enormous consumer traffic simply by virtue of their location.

The abundant and guaranteed consumer traffic to these out-of-downtown malls in Hong Kong distinguishes them from typical greenfield or brownfield shopping malls in North America and Europe in an important way. Because greenfield or brownfield malls do not usually have a large number of residents living within their walking distance, the attraction of shopper traffic is a central problematic in the management of malls. A common way to improve shopper traffic is to have a department store serve as an anchor (Dawson, 1983). Department stores work well as an anchor because the wide range of goods they carry appeal to a broad base of shoppers. Having a good anchor, the smaller and more specialized retail stores in a greenfield or brownfield mall will be more likely to receive a minimal amount of shopper traffic, which in turn contributes to the overall success of the mall (Hines and Clurman, 1988). This is the reason that department stores are usually given very favorable rental terms (relative to the smaller shops in the same mall) by the mall management. While an increasingly large number of older department stores in American downtown areas were closed down since the 1960s, new department stores were being established in suburban malls. Even though these new department stores have smaller floor spaces and less prestigious store images compared to conventional downtown department stores, they nonetheless provide a viable means of survival for the department store format. The regional department store chain in the US, for example, currently operates on the basis of a large number of smaller department stores in suburban malls and a small number of huge department stores in the downtown areas of major cities.

Because the out-of-downtown malls in Hong Kong do not require an anchor to attract consumer flow, they are not obliged to give any rental discount to department store tenants. According to one of my informants (an architect experienced in designing shopping malls), the managers of malls in Hong Kong generally appreciate the value of having a department store tenant, but they tend to see the department store tenant more as a prestige booster that directly attract prestigious specialty store chain tenants (eg. expensive global brandnames) than as an anchor for the mall. The majority of out-of-downtown malls in Hong Kong in fact do not feature any department store tenants. Hence, the survival of Hong Kong department stores cannot rely on their functioning as anchors in large shopping malls, and the institutional changes found in contemporary Hong Kong department stores are also not particularly oriented towards adaptation to the circumstances of Hong Kong's suburban shopping malls, as I will show.

\subsection{Downtown location and high rental rates}

Urban decay in American cities in the second half of the $20^{\text {th }}$ century forcefully undermined the downtown department store, though urban center regeneration is reversing the trend in the past decade. A host of inter-related negative impacts came with the decaying of downtowns, including the decrease of shopper traffic, change to a less affluent shopper base, and the tarnishing of store image. The downtown areas of Hong Kong have not gone through a similar process of urban decay. The oldest central business district, the Central, had always retained the most prestigious office buildings and shopping areas. Three other old business and shopping districts - Causeway Bay, Tsimshatsui, and Mongkok - have never ceased to be the busiest shopping districts in Hong Kong. No other geographic districts in Hong Kong surpass these four downtown areas in offering shopping facilities and prestige to stores, although a few new shopping districts (eg. the several interconnected malls in Shatin) may offer a similarly large amount of shopper traffic.

Instead of undergoing decay, the aforementioned four districts in Hong Kong underwent important renewals that strengthen their position as central shopping areas in the past three decades. Large and luxurious new shopping malls were built, older ones were linked together by various kinds of structures, and most malls are conveniently linked to mass transit railway stations in air-conditioned or automated walkways. In contrast to American downtowns, the 
downtown areas of Hong Kong never lacked affluent consumers, locational prestige, or upscale built environment in their surroundings.

The tendency for out-of-town malls in Hong Kong to not feature department stores in them, together with the fact that the old downtown districts remain to be the central shopping districts in Hong Kong, strongly pressures Hong Kong's department stores to remain located in downtown areas. Approximately half of all department stores in Hong Kong are located in the four major central shopping districts. Moreover, the department stores that are located in out-of town malls tend to be small and unprestigious. Examples include Seiyu in Shatin and Jusco in Tuen Mun. And the CitiStore chain of department stores, which specialize in out-of town mall locations, carry such a limited range of merchandize that they can hardly be recognized as department stores by a strict industrial definition.

The most significant consequence for Hong Kong department stores of remaining in downtown areas is their being forced to pay extremely high rents. In 1990, Hong Kong climbed to the second place in the world ranking of retail rental rates, closely following those of Tokyo (Phillips, Sternquist, and Mui, 1992). Hong Kong's real estate and retail rents continued to soar in the 1990s before the Asian Crisis, arriving at a peak of US \$693 per square foot in 1994 and still maintaining at \$642 in 1997 for the Causeway Bay district (Fellman, 1996; Jones Lang LaSalle, 1994-1997). Rental rates stayed at a low level for the first few years after 1997, but soared again in the past few years (Jones Lang LaSalle, 1998-2004). Although local department store chains owned some of the buildings where their stores are located, these stores still pay a high opportunity cost. The majority of foreign invested department stores had to bear the high rental rates. Japanese department stores, for example, were heavily affected by rent rates - some were forced to retreat from Hong Kong and others went through business restructuring or change of ownership. Some of the inherently inflexible cost features of the department store format became highly destructive with high rental rates. For example, department stores' need to carry a range of lower profitability (per retail area) merchandize seriously undermined the overall profitability of the store.

The impact of high rental rates was exacerbated by the unsympathetic attitude of real estate developers towards department stores. Department stores in Hong Kong get relatively short rental contracts. Hong Kong's real estate developers commonly arrange for two-year or three-year rental contracts for businesses tenants in order to gain more frequent opportunities to raise the rental rates; real estate prices in Hong Kong continue to soar year after year before 1997. At the same time, real estate developers have been reluctant to adjust the rental rates below the leasing contract when real estate prices plunged after the Asian Crisis. One of the reasons is that because real estate developers in general tend not to have a systematic long-term plan for marketing malls (Kirkup and Rafiq, 1999). But it is also because Hong Kong's particular urban formation does not at all pressure real estate developers to rely on or work with department stores, as I previously discussed.

\section{Concession as the major institutional adaptation of Hong Kong's department stores}

Not particularly needed by out-of-downtown malls and having to pay extremely high rents, department stores in Hong Kong have been undergoing pressure since the early 1990s to initiate institutional changes to ensure their profitability. Initially, few institutional changes were actually implemented because the local economic bubble provided strong consumer expenditures that kept profitability afloat. The rapid escalation of rental rates in the mid-1990s and the enormous negative impact of the Asian Crisis effectively forced the majority of surviving department stores in the late-1990s to implement significant institutional transformations. The most salient changes in the period between 1998 and the present may be summarized as a strategic transformation from the conventional department store format towards a concession-oriented department store structure.

'Concession' refers to the leasing of partitioned retail counters within a department store to concessionaires. Concessionaires include manufacturers, suppliers, or licensed importers that manage individual brands of products. Concession retail counters are often described as 'shops within shops,' a notion that vividly conveys the spatial, operational, and formal institutional fragmentation that they bring to department store. Concession is certainly not new or unique to Hong Kong. It has been adopted in the UK and the US by a range of large store formats in the past decades (McGoldrick, 1987; Worthington, 1985; 1988). It is also increasingly utilized at present by department store managers in the contemporary West to improve store competitiveness (Aldridge, 2004a; 2004b). Department stores also have the convention of make concession arrangements for a small and selected range of merchandize, the most notable of which is cosmetics.

Nonetheless, the extent to which concession is adopted by Hong Kong's department stores is extraordinary and warrants examination. According to my retail consultant and department store manager informants, all department stores apart from three chains in Hong Kong are devoting most of their prime floor areas and over $70 \%$ of their total retail floor space to concession counters. The Japanese department stores that rented their retail space instead of purchased it were hit hardest by the late-1990s' economic downturn, and they were the first to adopt concession for survival. For example, Sogo changed ownership in 1998 and the new management immediately turned the store into a collection of concession counters. The effort was very successful and by the present, Sogo devotes over $90 \%$ of space to concessions, many of 
which are the world's most prestigious brands. Locally owned chains were the slowest to adopt concession because of the conservative nature of their family-based management and in some cases ownership of their own retail premise. For example, the Sincere Chain did not begin to broadly adopt concession until around 2002, though they presently devote about $70 \%$ of their space to concession.

The three chains that did not dedicate more than half of their space to concession counters, including Lane Crawford, Uny, and Mark and Spencer, constitute informative counter-examples. Lane Crawford is an exceptional chain that successfully hybridizes the prestige apparel chain operations and the conventional department store format. Its stores carry a wider range of merchandise than the prestige apparel store and a narrower range of merchandise than the conventional department store. At the same time, all of them are premium price-range fashion products and most of the stores' floor space is assigned to apparel. The upscale nature of these stores makes it necessary for them to occupy prestigious downtown locations. They are more capable of paying the high rents because the high value of their merchandise render their retail space more productive than department store that carry merchandise with wider price ranges.

The Uny Chain was able to avoid the development toward a concession-oriented model mainly because it specializes in out-of-downtown locations. In contrast to the majority of Japanese department store chains, Uny placed its department stores exclusively in malls placed within large housing estates with tens of thousands of middle-class inhabitants. Rental rates in these locations are less exorbitant than downtown locations yet shopper traffic is equally abundant. The reason that the Mark and Spencer Chain avoids concession is clearly associated with its focus on selling own brand merchandise. Since Mark and Spencer stores tend to fill their retail space with own brand apparel, they do not have the option of pursuing concession as a major solution.

\section{Relationship between concessionaires and the department store}

To comprehend how concession-oriented department stores diverge from the conventional department store format, the most indispensable factor to investigate is the power play between the department store and its concessionaires. Concession arrangements involve complex cooperation, conflict of interests, and political negotiation between a department store and its concessionaires. From the point of view of the department store management, concessionaires not only need to help bear the overhead and operational costs of the store, they should also contribute to maximizing sales turnover and shopper traffic of the store. Department stores therefore usually welcome prestigious or popular brands to become their concessionaires. In addition, it also prefers concessionaires to offer as steep a discount as possible in store-wide sales and discount their merchandise as frequently as possible.

Manufacturers and retailers in Hong Kong set up concession arrangements with department stores because of risk and cost considerations. High retail rental rates threaten them, especially specialty chains and multiples that expand mainly through opening an increasingly large number of stores. Concession arrangements lower the risk of such expansion by means of lowering rental costs, and rental costs in Hong Kong constitute a large portion of a retailer's overhead and operational expenses. Concession terms typically allow the concessionaire to pay lower-than-market-value rents and make up for the low rent by sharing a certain percentage of their monthly profits with the department store. They may or may not end up making more profit by setting up a concession counter instead of a shop in a mall or on busy streets. But their risks of operational expansion are effectively lowered. Shopper traffic of the department store is also an inherent attraction of concession arrangement for manufacturers and retailers. However, it functions an important attraction primarily for new market entrants or non-established brands. Concessionaires typically ask the department store management to assign to them a good floor section within the department store as well as to attract shoppers through paying for the store's centralized marketing and advertisement services.

In setting up a concession contract, the department store and the concessionaire negotiate on rental rates, profit sharing terms, advertising costs sharing terms, and other secondary details. For example, an informant (manager of a leading local casual wear brand) reveals that her company pays a rental rate of HKD 250 per square feet at a major Causeway Bay department store, which is slightly less than half of the average market rental value. The counter pays between $20 \%$ and $25 \%$ of its profit to the department store. Contract terms can vary a great deal, depending on the relatively power of the department store and the concessionaire.

Consignment, an arrangement that is in some aspects similar to concession, is not widely adopted by Hong Kong's department stores. In a consignment arrangement, a manufacturer or retailer places their brand merchandise in a department store for sale and shares the profit from sales of the merchandise with the store. To Hong Kong's manufacturers and retailers, consignment may be seen as a limited version of concession with the similar functions of risk control, guaranteed shopper traffic, and lowered rents. However, consignment is much less attractive than concession to the department store management, even though consignment involves a smaller degree of deviation from the conventional department store format. It is because in contrast to concession, consignment contributes very little to the lowering of overhead and operational costs of department stores. Consignment mainly lowers merchandise and inventory costs, but Hong Kong's department stores primarily focus on controlling their rent and staff costs. 


\section{Institutional changes brought about by concession arrangements}

The turning of over $70 \%$ of the retail floor space of a department store into concession counters - as most of Hong Kong's departments stores do - leads the store far away from the conventional department store format. Significant operation and structural changes are entailed. The most notable change involves that of merchandizing and buying operations. If estimated indirectly via retail floor space, only $10 \%$ to $30 \%$ of the merchandise of Hong Kong's department stores are directly selected, acquired, and managed by the store staff. The rest is under the management of the individual brands that constitute the concessionaires of the department stores.

The shift of a large percentage of the department stores' buying and merchandizing workload to the concessionaires necessitates changes to the department stores' buying and merchandizing departments. In some cases, buying and merchandizing departments are downsized, and new departments are built to deal with the concession related work. In other cases, buying and merchandizing staffs are kept and the departments are re-tuned to deal with the new workload. For instance, menswear merchandisers may pick up the work of selection and management of menswear concessionaires.

With the incoming of numerous concessionaires, new types of routine work are created. Examples include the selection and contracting of new concessionaires, or the management of existing concessionaires. Not anymore focusing singly on store merchandise, these kinds of work are very different from the conventional buying, merchandizing, or sales work processes of a department store. They focus instead on management of the concessionaire tenant mix, negotiation with individual brands, and mobilization and coordination of the department store's concessionaires for collective goals. These work processes may be described as a cross-over between those of a shopping mall manager and those of a conventional department store manager.

Another notable institutional change in Hong Kong's department stores resulting from concession involves frontline sales assistants. Most concessionaires hire and train their own sale personnel to work at concession counters in department stores. Hong Kong's department stores therefore tend to lay off the majority of their sales assistants and relegate frontline sales work to concessionaires. Sales managers are usually kept, however. Even though their workload of training and managing sales assistants are minimized, the sales assistants and sales work of concessionaires still need to be monitored, indirectly managed, and coordinated.

In addition to buying, merchandizing, and frontline sales, the work of visual merchandizing is also partly shifted to concessionaires. Both prestigious fashion brands and middle price range large apparel chains want to centrally manage visual merchandizing of all their store counters in Hong Kong in order to manage brand image. They have specialized personnel to take care of the visual merchandizing of their concession counters. Concessionaires are sometimes allowed to take over the visual merchandizing in the department store's display window if their counters occupy the prime window spots of the store. But Hong Kong's department stores still tend to keep a number of visual merchandizing staff for the work of window display and signage. The coordination of brands in the same floor section is also a vital visual merchandizing work for concession-oriented department stores. The symbolism (including a range of items such as posters and music) and interior design of a cluster of concession counters in a floor section are bound to be very different. Without proper coordination, the floor section as a whole may turn into an unattractive shopping environment. It is the responsibility of the department store's visual merchandizing staff to deal with these potential problems.

Cashier work can in principle be easily shifted to concessionaires, but the majority of Hong Kong department stores prefer to keep it to the store. Central administration of cashiering helps the department store to keep track of the turnover figures of all concessionaires. Even if the data may not be required for retail information systems (since the concessionaires will do such analyses for themselves), they are needed as a database for the sharing of profits between the department store and individual concessionaires.

Subtle changes are introduced into marketing, advertising, and sales campaigning of Hong Kong's department stores by a concession-oriented business model. The management and building of a department store brand can become very different when the store is not the one who merchandizes. The merchandise sold in Hong Kong's department store is selected by the buyers and merchandisers of concessionaires. The department store still gets to choose its own particular mix of brand suppliers, thereby indirectly affecting the range of merchandise sold in store. Yet brands that are available to set up concession counters in Hong Kong's department stores are not unlimited in supply. They are largely limited to local brands, East Asian ones, and established global ones from Europe and North America. Moreover, concessionaires tend to offer very similar merchandise in their concession counters in different department stores.

In general, the work of department store brand-building is complicated as well as undermined. For example, local department store chains used to market their merchandise through making and distributing their own catalogs in the 1990s. At present, they have stopped making department store catalogs altogether. The Lane Crawford chain, which still merchandize a comparatively large share of its merchandise, is perhaps the only department store can still make use of catalogs in Hong Kong. It is not clear how department store catalogs should differentiate from their competitors' when 
more than $70 \%$ of the store's merchandise is entirely decided by concessionaires.

The efforts and strategies of concession-oriented department stores to advertise also diverge from that of conventional department stores. Their advertisement contents tend to avoid foregrounding the reality of the store as a highly decentralized institution with numerous concession counters. Otherwise it may devolve into advertisement for a disparate collection of individual brands. But presenting the department store as an integral whole is not always plausible and truthful under the new circumstances. For instance, department store sale ads in Hong Kong used to attract shoppers through detailing how much exactly specific products are discounted. Such a type of ads is currently uncommon because concessionaires might consider it as a threat to their brands' prestige and it is also difficult for department stores to balance the interest of various concessionaires when specific products are named in ads.

Sales campaigns, a powerful and frequently used marketing method in the Chinese context, become one of the focal points of power political contentions between department stores and their concessionaires. Increased shopper traffic and turnover during sale campaigns benefit department store as well as concessionaires. However, sale campaigns usually cost concessionaires more than department stores. In a concession-oriented department store, merchandise that is discounted is not paid for by the department store. In other words, the price reduction necessitated by the sale burdens concessionaires much more than department stores. No wonder an informant (a middle level manager of a local department store chain) observes that sales campaigns are almost two times more frequent than before after her department store had adopted a concession-oriented model. Concessionaires are also reluctant to accept the steep discount rate that department stores tend to fix collectively for store-wide campaigns. The department store does not in principle need to consider how sale campaigns negatively affect individual concessionaires. If a concessionaire's brand image and profitability are hurt because of frequent sales, the department store does not directly bear the consequences anyways. Negotiations with concessionaires on discount rates have become one of the onerous routine of the department store management in Hong Kong.

\section{Discussion and Conclusion}

I have elaborated how the concession-oriented department store deviates in various ways from the conventional department store format. Buying, merchandizing, and front-line sales functions are greatly reduced. Negotiation with concessionaires and management of them in order to ensure rent revenue become a central operational focus. The management of a concession-oriented department store to some extent resembles that of a shopping mall, and the operation of a concession-oriented department store to a certain degree resembles that of a real estate business.

The adoption of the concession-oriented model in Hong Kong represents a viable way through which department stores can cope with the conventional department store format's inherent weaknesses in comparison with specialty stores. Instead of competing head-to-head against specialty stores, Hong Kong's department stores choose to join forces with specialty brand manufacturers and retailers. The concession-oriented department store is practically outsourcing its major retailing functions to specialty stores.

From the point of view of retail change theory, the rise of the concession-oriented model may be interpreted as a dialectic synthesis of the shopping mall format and the conventional department store triggered by the retail environment of high rental rates, downtown locations, and anchorless malls in Hong Kong. The dialectic theory highlights how two different competitive retail formats institutionally shift towards each other to generate a new hybrid format that contains the advantages of both (Maronick and Walker, 1974). On the one hand, specialty stores could gain additional advantages from setting up concession counters in department stores because they can benefit from the department store's shopper traffic, lowered rental rates, department store brand, and experienced retail management. On the other hand, department stores are challenged by high rents, a serious threat that has rendered the concession-oriented business model acceptable to Hong Kong's department store management. So far, the concession model has been quite successful. It has helped many Hong Kong's department stores to stay profitable and has attracted numerous prestigious brands to the concession counter option.

The concession-oriented model is not without potential problems, however. The difficulty it produces for department store brand building, the coordination problem involved with incoherent visual merchandizing in a floor section, or the great efforts needed to mobilize concessionaries for any collective efforts are some examples. The future experiences of Hong Kong's department stores will certainly inform us more about these and other emergent problems of the concession-oriented department store format.

The considerable institutional changes of Hong Kong's department store should also alert retail scholars to the great extent to which department stores across the globe can vary in responding to the decline of the conventional department store format. A fruitful research direction for future studies will be to explore this global variation in other parts of Asia as well as other non-Western countries. A comparison of the divergent institutional adaptations of the department store in different parts of the world not only informs us on how the retail business is doing in different localities, but also promises to offer theoretical insights on retail change and competitive retail formats. 


\section{References}

Aldridge, A. (2004a). Department stores offer a touch of retail magic. Marketing, Nov 24, pp.15.

Aldridge, A. (2004b). Retailers find there's cash in concessions. Marketing, Sept 15, pp.15.

Chong, L. (1996). Department stores in troubled waters: a Singapore encounter. International Journal of Retail and Distribution Management, 24 (1), 34-39.

Dawson, J.A. (1983) Shopping Centre Development, London: Longman.

Fellman, J. (1996). Causeway Bay on top of the world for shop rents. Hong Kong Standard, Dec 24.

Haines, G. H., Simon, J.R. \& Alexis, M. (1971). The dynamics of commercial structure in central city areas. Journal of Marketing, 35(April), 10-18.

Hines, M. A. \& Clurman, E. D. (1988). Shopping Centre Development and Investment (2nd ed.). New York: John Wiley \& Sons, Inc.

Jones Lang LaSalle. (1994-2004). Asia Pacific Property Digest. Hong Kong: Jones Lang LaSalle.

Kirkup, M. H. \& Rafiq, M. (1999). Marketing shopping centres: challenges in the UK context. Journal of Marketing Practice: Applied Marketing Science, 5 (5), 119-133.

Maronick, T. J. \& Walker, B. J. (1974). The Dialectic Evolution of Retailing. Proceedings: Southern Marketing Association, Atlanta: Georgia State University.

May, E. G. \& McNair, M. P. (1977). Department stores face stiff challenge in next decade. Journal of Retailing, 53(Fall), 47-58.

McGoldrick, P. J. (1987). Shops within shops: the consumer viewpoint. Retail and Distribution Management, 15(4), 9-12.

Phillips, L. A., Sternquist, B.. J. \& Mui, S. (1992). Hong Kong department stores: retailing in the 1990s. International Journal of Retail and Distribution Management, 20(1), 16-24.

Simmons, J. \& Chan, K. W. (1992). The retail structure of Hong Kong. Centre of Urban Planning and Environment Management Working Paper number 53, The University of Hong Kong.

Sternlieb, G. \& Hughes, J. W. (1987). The demise of the department store. American Demographics, 9 (8), $30-32$ and 59.

Sun, N.L.V., Kay, R. \& Chew, M. M. (2008 forthcoming). Development of a retail life cycle: the case of the department store industry in Hong Kong. Asia Pacific Business Review.

Willans, J. (1996). Department store: an enduring retail format. Journal of Fashion Marketing and Management, 1(2), 146-150.

Worthington, S. (1988). Concessionaires — a strategic option for retailers", European Journal of Marketing, 22 (3), 14-20.

Worthington, S. (1985). Shops within shops: the concessionaire's point of view. Retail and Distribution Management, Vol. 13, No. 5; p. 32-5. 